\title{
PERSPEKTIF KODE ETIK JABATAN NOTARIS TERHADAP PUB- LIKASI DAN PROMOSI JABATAN NOTARIS MELALUI APLIKASI ANDROID
}

\author{
Nadia Imanda \\ Fakultas Hukum Universitas Airlangga \\ Jalan Dharmawangsa Dalam Selatan, Surabaya, 60286, Indonesia \\ Telp/Fax: (031) 5023151 Email: nadia.imanda96@gmail.com
}

Submitted : 31/08/2019 Reviewed 28/02/2019 Accepted:06/03/2020

\begin{abstract}
The era of technology brings people to the development of sophisticated computers and smartphones in which the applications of various types and purposes are. Notary as a public official appointed by the state to take care of most countries and communities in the context of civil law, has legal provisions related to what may and may not be done by a Notary. In this case, the Notary Code of Ethics of the Indonesian Notary Association (INI) states that notaries are denied publication and self-promotion of their positions through writing media as well as electronic media, but the category of advertising on publicity and self-promotion does not provide clear interpretation on android application that indicates to violate the Article 4 paragraph (3) Notary Code of Ethics. This legal research uses normative research methods using the statute approach and conceptual approaches. The use of an android application by a notary who indicates committing violation must be studied and supervised from the Notary Honorary Board and Notary Supervisory Board so that the inteniont and the purpose of the UUJN and the Notary Code of Ethics can be realized and the office of notary as a profession cannot be dishonored.
\end{abstract}

Keywords: Notary Code of Ethics; Publication; Promotion; Profession of Notary; Android Application.

\begin{abstract}
Abstrak: Era teknologi membawa manusia pada perkembangan komputer dan smartphone canggih yang di dalamnya terdapat fasilitas aplikasi berbagai macam jenis dan tujuan. Notaris sebagai pejabat umum yang diangkat oleh negara untuk mengurusi sebagian urusan negara dan masyarakat dalam lingkup hukum perdata, memiliki ketentuan hukum terkait apa yang boleh dan tidak boleh dilakukan oleh seorang Notaris. Dalam hal ini, Kode Etik Notaris Ikatan Notaris Indonesia (I.N.I) menyatakan bahwa notaris dilarang melak ukan publikasi dan promosi diri terhadap jabatannya melalui media tulis mau pun media elektronik, namun kategori
\end{abstract}


batasan terhadap publikasi dan promosi diri dinilai kurang memberikan kejelasan hukum bahwasanya ditemukan aplikasi android yang berindikasi pelanggaran Pasal 4 ayat (3) Kode Etik Notaris. Penelitian hukum ini menggunakan metode penelitian normatif dengan pendekatan berdasarkan perundang-undangan (statute approach) dan pendekatan konsep (conceptual approach). Penggunaan aplikasi android oleh notaris yang berindikasi melakukan pelanggaran harus dilakukan pengkajian dan pengawasan dari Dewan Kehormatan Notaris dan Majelis Pengawas Notaris agar maksud dan tujuan UUJN serta Kode Etik Notaris dapat terwujud dan tidak mencederai jabatan notaris sebagai profesi yang mulia.

\section{Kata Kunci: Kode Etik; Publikasi; Promosi; Jabatan Notaris; Aplikasi Android.}

\section{PENDAHULUAN}

Undang-undang Nomor 2 tahun 2014 tentang Perubahan atas Undang-undang Nomor 30 Tahun 2004 tentang Jabatan Notaris (selanjutnya ditulis UUJN) merupakan pedoman bagi Notaris dalam menjalankan profesinya. Selain UUJN, Notaris juga harus menjunjung tinggi kode etiknya sebagai seorang pejabat umum yang merupakan perpanjangan tangan dari pemerintah untuk mengurusi hal-hal yang telah menjadi kewenangannya sebagaimana diamatkan oleh UUJN Pasal 15 ayat (1), (2) dan (3).

Kedudukan seorang notaris sebagai pejabat umum hingga saat ini dirasakan masih disegani oleh masyarakat. Seorang notaris merupakan tempat masyarakat maupun kelompok bisnis tertentu, memperoleh suatu nasihat hukum yang dapat diandalkan. Hal yang diusulkan oleh notaris sebagai bagian dari nasihat hukumnya dipercaya ampuh dan tidak memihak pada suatu kelompok atau golongan tertentu sebab hal itu termaktub dalam sumpah jabatannya sebagai seorang notaris, begitu juga dengan produk hukum yang dikeluarkan notaris, dalam hal ini adalah dokumen yang kuat dalam suatu proses hukum. ${ }^{1}$

1 Tan Thong Kie. 2007. Studi Notariat dan SerbaSerbi Praktek Notaris, cet. 1, Jakarta: PT. Ichtiar
Sehingga dapat dilihat bahwa, profesi jabatan Notaris adalah suatu pekerjaan khusus yang membutuhkan keahlian yang khusus pula serta pengetahuan luas dan diikuti oleh tanggung jawab yang berat dalam melayani masyarakat di bidang hukum perdata. ${ }^{2}$ Oleh sebab itu, Notaris diwajibkan memiliki sifat yang amanah atau dapat dipercaya oleh kliennya, masyarakat umum serta negara, notaris juga wajib bersifat independen atau mandiri dimana seorang notaris tidak boleh bergantung pada suatu instansi atau lembaga apa pun dalam melaksanakan praktiknya, ia berhak untuk menolak jika suatu hal berindikasi pada keberpihakannya sebagai seorang notaris.

Seiring berjalannya waktu dan berkembangnya dunia teknologi, notaris dalam menjalankan tugas dan wewenangnya mendapat kemudahan dari teknologi tersebut, beberapa pelayanan hukum sudah beralih dengan akses daring (online) yang dapat digunakan melalui komputer, seperti dalam proses pendaftaran akta pendirian Commanditaire Venootschap (CV), Perseroan Terbatas (PT) dan Firma di-

Baru van Hoeve, hlm. 444.

2 Ghansam Anand. 2018. Karakteristik Jabatan Notaris di Indonesia, Jakarta: Prenamedia Group, hlm. 108. 
lakukan dengan menggunakan sistem milik Kementerian Hukum dan Hak Asasi Manusia yaitu Sistem Administrasi Badan Usaha (SABU).

Beberapa Notaris kian memanfaatkan kemajuan teknologi yang pesat dengan ditemukannya beberapa aplikasi notaris pada Google Play untuk pengguna OS Android, yang dibuat untuk mempermudah dalam melakukan pekerjaan notaris dan hubungan dengan klien-kliennya. Hal ini dapat dilihat sebagai sebuah terobosan baru dalam dunia kenotariatan sebab menggunakan aplikasi android dapat memudahkan pelayanan hukum dari notaris kepada masyakarat apabila pemanfaatannya dilakukan secara optimal dan tidak melanggar ketentuan hukum, yang diatur dalam UUJN dan Kode Etik Jabatan Notaris.

Terdapat berbagai jenis dan model aplikasi android pada toko aplikasi di dalam smartphone yang dapat diunduh menggunakan internet kemudian diakses secara mudah dan bebas. Model serta desainnya dapat ditentukan sendiri oleh pemangku kepentingan, dalam hal ini notaris, agar dapat memenuhi kebutuhan notaris beserta klien-kliennya. Contoh aplikasi android notaris adalah sebagai berikut:

1. Aplikasi Notaris dan PPAT Michael, S.H., S.T., M.Kn;

2. Aplikasi Notaris dan PPAT H. Moh. Makmun, S.H., M.Kn;

3. Aplikasi Notaris dan PPAT Jusuf Patrianto Tjahjono, S.H. M.H.

Pada penelitian hukum ini akan dibahas mengenai fungsi dari aplikasi android tersebut dalam dunia kenotariatan dilihat dari perspektif kode etik jabatan notaris, yang mengatur terkait publikasi dan promosi terhadap jabatannya sebagai seorang notaris. Aplikasi notaris dapat diakses secara luas dan bebas oleh masyarakat, yang dimana hal ini akan berpotensi menciptakan suatu persaingan usaha yang tidak sehat antar sesama rekan notaris dikemudian hari. Maka perlu dikaji secara mendalam mengenai batasan atas kegiatan publikasi dan promosi jabatan notaris sebagaimana disebutkan dalam Pasal 4 ayat (3) Kode Etik Notaris.

Berangkat dari latar belakang permasalahan di atas, maka perumusan masalah yang akan dikaji dalam penelitian ini adalah:

1. Bagaimana Penggunaan Aplikasi Android Oleh Notaris Berkaitan dengan Jabatannya sebagai Notaris?

2. Bagaimana Perspektif Kode Etik Jabatan Notaris Terhadap Publikasi dan Promosi Jabatan Notaris?

3. Bagaimana Timbulnya Persaingan Tidak Sehat Antar Sesama Rekan Notaris Disebabkan oleh Pelanggaran Kode Etik Jabatan Notaris?

\section{METODE}

Penelitian hukum normatif merupakan jenis penelitian hukum yang digunakan dalam penelitian ini. Penelitian hukum normatif bertumpu pada suatu metode yang terfokus pada penelitian hukum kepustakaan dengan menggunakan bahan pustaka, serta peraturan perundang-undangan. Tipe penelitian hukum ini menggunakan tipe penelitian normatif yang sistematika hukumnya mempelajari dan menganalisis mengenai perspektif kode etik jabatan notaris terhadap publikasi dan promosi jabatan notaris melalui aplikasi android.

Dalam penelitian hukum ini digunakan pendekatan berdasarkan peraturan perundang-undangan (Statute Approach), dan pendekatan konsep (Conceptual Approach). Statute Approach merupakan pendekatan menggunakan undang-undang dan regulasi 
yang berkaitan dengan isu hukum yang akan dibahas secara mendalam. ${ }^{3}$ Pendekatan ini mendasar pada ketentuan hukum tertulis yaitu peraturan perundang-undangan yang khusus berkaitan dengan tugas dan wewenang notaris, kewajiban serta larangan jabatannya.

Conceptual Approach ${ }^{4}$ yaitu sebuah konsep yang berfokus pada penggunaan doktrin sarjana hukum ahli yang diakui dalam ilmu hukum agar memenuhi tujuan untuk memberikan ide-ide hukum dan kejelasan terhadap isu hukum terkait publikasi dan promosi diri jabatan notaris.

Bahan hukum primer yang akan digunakan untuk menunjang penulisan, penyusunan serta penyajian penelitian hukum ini adalah ketentuan-ketentuan hukum dalam Burgerlijk Wetbook (BW), UUJN dan Kode Etik Notaris I.N.I., serta bahan hukum sekunder terkait buku, literature, hasil tulis para ahli hukum dan doktrin yang relevan dengan pembahasan pada penelitian hukum ini.

Teknik pengumpulan bahan hukum pada penelitian ini menggunakan studi dokumen (studi kepustakaan). Analisa bahan hukum primer dan bahan hukum sekunder dilakukan dengan metode interpretasi sistematis, lalu ditafsirkan dengan rumusan masalah penelitian terkait perspektif kode etik notaris terhadap publikasi dan promosi jabatan notaris melalui aplikasi android dan timbulnya persaingan usaha tidak sehat antar sesama rekan notaris akibat publikasi dan promosi jabatan notaris melalui aplikasi android tersebut.

\section{ANALISIS DAN PEMBAHASAN \\ Penggunaan Aplikasi Android Oleh Notar- is Berkaitan dengan Jabatannya sebagai}

3 Peter Mahmud Marzuki. 2010. Penelitian Hukum, Kencana Jakarta: Prenada Media Group, hlm.9697.

$4 \quad$ Ibid, hlm. 137.

\section{Notaris}

Salah satu perangkat populer saat ini yang sering digunakan sebagai media pembelajaran maupun media sosialisasi adalah perangkat berbasis Android, sehingga keberadaan perangkat teknologi informasi dan komunikasi semacam perangkat Android sulit dipisahkan dari lingkungan masyarakat, termasuk dunia kenotariatan yang dapat dilihat dari munculnya beberapa aplikasi Android yang sengaja dibuat untuk mencapai tujuan tertentu yang dapat diakses secara bebas oleh masyarakat umum. Tingkat efektivitas dan efisiensinya yang lebih baik dibandingkan dengan program jenis lainnya, misal Mobile Window atau sistem operasi Symbian membuat Android tergolong pada sistem operasi yang cepat dan popular.

Android merupakan suatu sistem operasi dengan sumber terbuka. Pada dasarnya, Android mempunyai banyak komunitas pengembang aplikasi (apps) yang memperluas fungsional perangkat tersebut, umumnya ditulis dalam versi kustomisasi Bahasa pemrograman Java. Data pada bulan Oktober 2013 menunjukkan bahwa Google Play sebagai toko aplikasi utama Android telah menaungi lebih dari satu juta aplikasi yang beraneka ragam dan telah diunduh sebanyak 50 miliar kali oleh para penggunanya. ${ }^{5}$ Pembuatan suatu aplikasi Android membutuhkan keahlian dalam bidang Bahasa pemrograman Java yang tergolong rumit. ${ }^{6}$ Sehingga butuh suatu keahlian dan pengetahuan khusus untuk membuat sebuah aplikasi android.

5 Aulia Rahman. 2019. Cara Membuat Aplikasi Android: Hanya 5 menit, Luminos Publish, hlm.67.

6 Ani Ismayani, 2018.Cara Mudah Membuat Aplikasi Pembelajaran Berbasis Android dengan Thunkable, Jakarta: Elex Media Komputindo, hlm.3 
Pada toko aplikasi Android, yaitu Google Play, terdapat beberapa aplikasi yang berkaitan dengan jabatan Notaris, sebagai berikut:

1. Aplikasi Notaris dan PPAT Michael, S.H., S.T., M.Kn

Pada menu utama aplikasi ini berisi foto notaris beserta tim dan beberapa artikel informatif, sementara itu juga terdapat profil notaris beserta tim, jasa notaris, jasa PPAT, serta berbagai jenis jasa yang ditawarkan oleh notaris/PPAT tersebut. Pada awalnya, penulis mengunduh dan mengakses aplikasi pada tanggal 26 September 2018 yang dimana aplikasi dapat diakses secara bebas oleh masyarakat dan berfungsi dengan baik, namun jika dilakukan pengunduhan saat ini, aplikasi tersebut tidak dapat digunakan sebab telah di blokir akses dan tidak dapat dibuka kembali. ${ }^{7}$ Berikut tangkapan layar aplikasi notaris Michael, S.h., S.T., M.Kn diakses pada tanggal 26 September 2018:
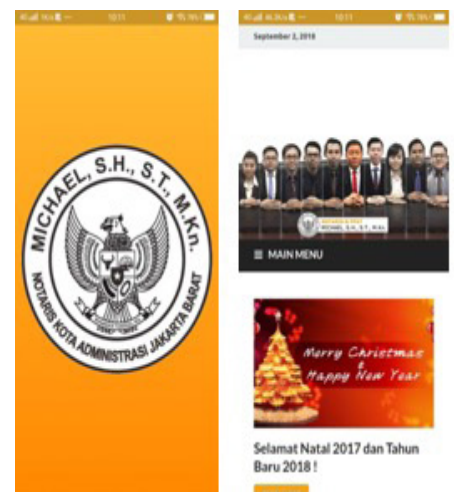

Gambar 1.0 Gambar 1.2 Gambar 1.3

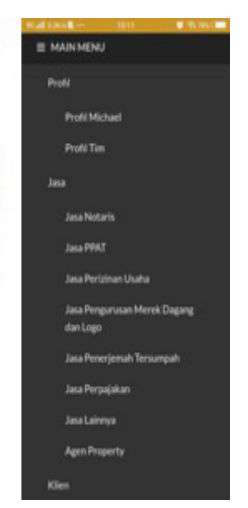

2. Aplikasi Notaris dan PPAT Jusuf Patrianto Tjahjono, S.H., M.H.

Pada aplikasi ini, calon pengguna diharap membuat/mendaftar akun baru (apabila belum memilikinya), dengan cara memasukkan alamat email dan password, setelah langkah

7 Diakses pada tanggal 18 Juli 2019, pukul 20.00 WIB. tersebut berhasil maka tampilan aplikasi ini memuat menu utama, terdapat kolom bertuliskan "Promo", "Voucher", dan "Product", namun ketika di klik hanya memunculkan tulisan "Sorry, we could't find any matches. Please try again.".

Aplikasi ini termasuk aplikasi "kosongan" yang tidak berisi apapun kecuali pada kolom "About Us" tertulis "Notaris dan PPAT di Kota Surabaya dengan motto "Melayani dengan P.A.S.T.I"" dan pada kolom "Contact Us" yang berisi nama kantor notaris, wilayah kerja notaris, alamat, nomor telepon, dan jam operasional kantor notaris. Berikut tangkapan layar aplikasi Notaris dan PPAT Jusuf Patrianto Tjahjono, S.H., M.H. Berikut tangkapan layar aplikasi Notaris dan PPAT Jusuf Patrianto Tjahjono, S.H., M.H

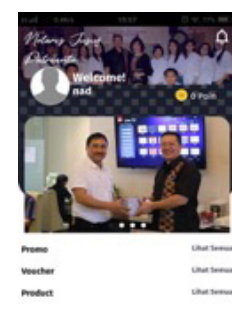

$\underline{\Delta} \pm \underline{2} \underline{-2}$

Gambar 2.0

Gambar 2.3

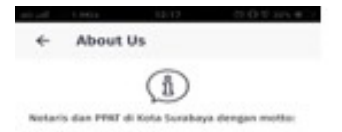

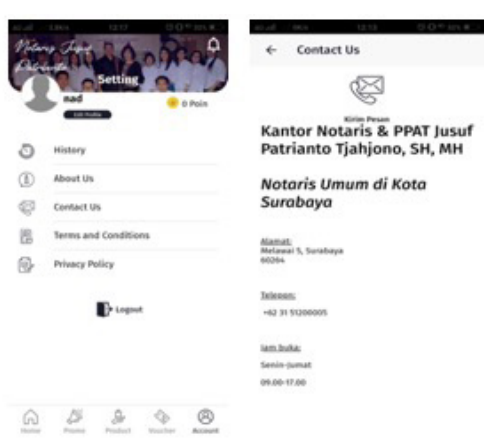

Gambar 2.2
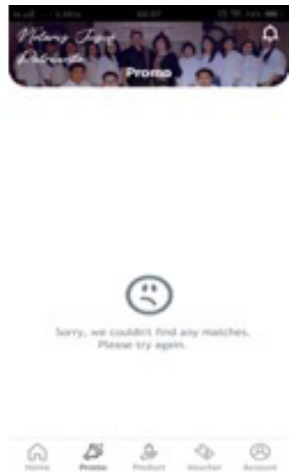

Gambar 2.4

8 Diakses pada tanggal 18 Juli 2019, pukul 20.50 WIB. 
3. Aplikasi Notaris dan PPAT H. Moh. Makmun, S.H., M.Kn

Pada aplikasi ini hanya memuat logo Ikatan Notaris Indonesia (I.N.I), nama notaris yaitu H.Moh.Makmun, S.H., M.Kn serta tulisan “Masukkan No Berkas Anda!'. Aplikasi ini tidak dapat digunakan oleh orang lain selain daripada klien notaris/PPAT tersebut, artinya aplikasi ini tidak dapat diakses secara bebas kecuali pengguna memiliki nomor berkas yang sesuai maka akan tampil berkas dengan nomor tersebut.

Dilihat dari tampilannya, aplikasi ini berfungsi untuk memudahkan klien notaris dalam memantau status berkas maupun melakukan kontak dengan kantor notaris/PPAT. Pada aplikasi ini juga perlu diperhatikan bahwa tidak terdapat keterangan wilayah kerja daripada notaris/PPAT itu sendiri, sehingga penulis tidak melihat adanya unsur promosi yang disengaja oleh notaris yang bersangkutan. Berikut merupakan tangkapan layar aplikasi tersebut: ${ }^{9}$

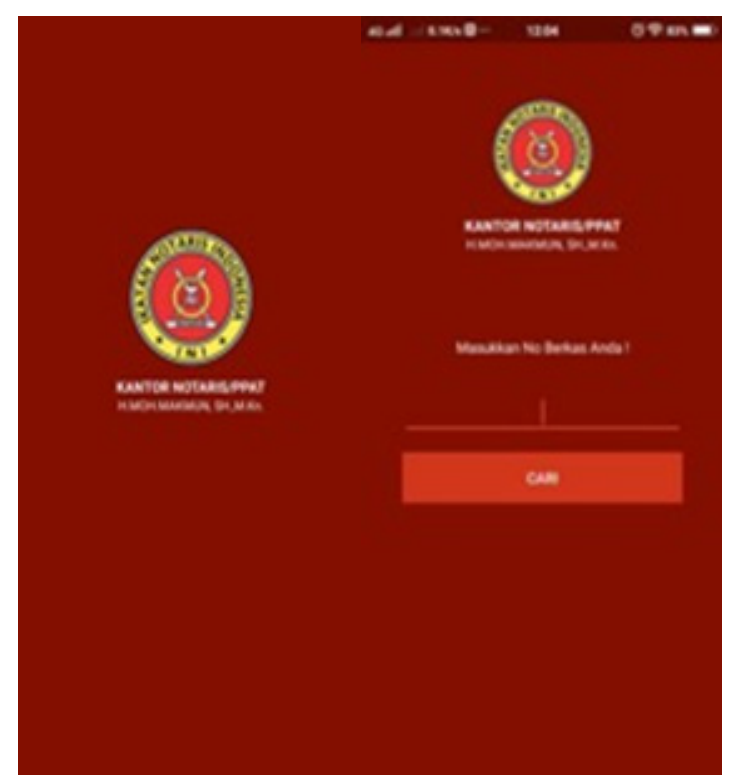

Gambar 3.0

Gambar 3.1

9 Diakses pada tanggal 18 Juli 2019, pukul 21.05 WIB.
Ketiga aplikasi android di atas memiliki fungsi dan tujuan yang berbeda-beda. Hal inilah yang membedakan adanya pelanggaran publikasi atau promosi diri dalam bentuk media elektronik aplikasi smartphone atau tidak.

Penggunaan aplikasi android oleh notaris merupakan terobosan menarik dalam dunia kenotariatan yang dapat menjadi suatu inovasi tersendiri dalam memberikan pelayanan yang prima kepada klien notaris, namun sebelum melangkah lebih jauh disarankan agar lebih memperhatikan hakikat dari fungsi dan tujuan penggunaan aplikasi android tersebut. Alangkah baiknya jika aplikasi android yang digunakan oleh notaris dibuat untuk memudahkan klien sepenuhnya tanpa adanya unsur publikasi dan promosi jabatan notaris.

\section{Analisis Kode Etik Jabatan Notaris Ter- hadap Publikasi dan Promosi Jabatan No- taris}

Notaris ialah suatu profesi jabatan yang berintegritas tinggi, maka dalam menjalankan jabatannya seorang notaris haruslah berlandasan kerja yang idiil dan menjunjung etos kerja yang tinggi, maka agar dapat mencapai standar kerja notaris yang prima, notaris memiliki panduan yaitu Kode Etik Jabatan Notaris yang berfungsi untuk membantu notaris memahami moral dan etika profesinya.

Fungsi etika bagi notaris meliputi empat jenis norma, yaitu:

a. norma agama, merupakan aturan dari Tuhan dan ditegakkan oleh perangkat agama;

b. norma hukum, adalah norma yang dibuat oleh penguasa (negara) dan memiliki sanksi yang tegas;

c. norma kesusilaan, merupakan norma yang mengatur secara universal tentang kehidupan manusia secara hu- 
manistik; dan

d. norma kesopanan, yang bersifat particular atau khusus mengatur masyarakat tertentu dan ditegakkan oleh masyarakat tertentu tersebut.

Norma-norma tersebut saling bertaut satu sama lain, yang kemudian mencerminkan etika dan moral yang baik, jika dipatuhi dalam menjalankan pekerjaan atau profesi apapun. Berkaitan dengan notaris yang telah diatur secara spesifik dalam UUJN dan Kode Etik Jabatan Notaris untuk dijadikan kompas dan standarisasi sikap seorang notaris.

Diterangkan dalam Pasal 4 angka 3 Kode Etik Jabatan Notaris yang memuat bentuk larangan yang tidak boleh dilakukan oleh Notaris, bahwa Notaris maupun notaris pengganti dilarang melakukan publikasi atau promosi diri, baik sendiri maupun secara bersama-sama dengan mencantumkan nama dan jabatannya, menggunakan sarana media cetak dan/atau elektronik.

Akan tetapi, sebagaimana diketahui pada Pasal 5 memuat materi pengecualian pada perilaku tertentu yang tidak termasuk Pelanggaran, terutama pada Pasal 5 huruf d mengatur tentang pengecualian notaris yang dapat memperkenalkan diri tetapi tidak melakukan promosi diri selaku Notaris.

Maka, pada dasarnya Kode Etik Jabatan Notaris hanya mengatur perilaku menjalankan jabatannya dan tidak mengatur tentang kehidupan sehari-hari notaris, seperti halnya seorang yang menjalankan jabatan Notaris dilarang melakukan publikasi atau promosi diri terkait jabatan yang diembannya selain daripada pengecualian yang dinyatakan dalam Pasal 5 Kode Etik Jabatan Notaris sebab dapat mempengaruhi gambaran diri serta martabat Notaris sebagai seorang Pejabat umum dan mengindikasikan adanya persaingan tidak se- hat antara sesama rekan Notaris.

Perlu diketahui, publikasi dan promosi itu sendiri adalah dua kata yang berbeda arti. Publikasi merupakan pembuatan konten yang diperuntukkan bagi publik atau umum, sedangkan promosi adalah upaya untuk memberitahukan atau menawarkan produk atau jasa pada dengan tujuan menarik calon konsumen dengan tujuan untuk memberi atau mengkonsumsinya. ${ }^{10}$ Sedangkan, Undang-undang Nomor 8 Tahun 1999 tentang Perlindungan Konsumen menyebutkan bahwa promosi adalah kegiatan pengenalan atau penyebarluasan informasi suatu barang dan/atau jasa untuk menarik minat beli konsumen terhadap barang dan/atau jasa yang akan dan sedang diperdagangkan. . ${ }^{11}$

Dengan adanya perbedaan mendasar dari pengertian di atas bahwa publikasi lebih ditekankan pada aspek konten yang sengaja dibuat dengan tujuan tertentu yang diperuntukkan bagi masyarakat umum, sedangkan promosi menekankan pada aspek pemasaran dari suatu produk dan/atau jasa sehingga memperoleh keuntungan lebih daripadanya.

Larangan publikasi atau promosi diri tersebut merupakan hal yang wajar jika dibandingkan antar notaris sebagai pejabat umum dan pengusaha/kantor Badan Usaha yang pada dasarnya membutuhkan publikasi dan promosi diri dalam rangka menggapai kesuksesan usahanya. Sehingga, notaris tidak dapat dibenarkan apabila melakukan publikasi atau promosi diri untuk menarik calon

10 Irvano Gibriansyah Harsono. 2019. Larangan Etika Terkait Publikasi dan Promosi Jabatan Bagi Notaris Melalui Media Elektronik, Tesis, Universitas Airlangga, hlm. 6.

11 Pasal 1 angka 6 Undang-undang Nomor 8 Tahun 1999 tentang Perlindungan Konsumen. 
klien. ${ }^{12}$

Notaris sebagai pelayan negara di bidang hukum perdata yang diangkat untuk melayani kepentingan masyarakat tidak bisa disamakan dengan pelayanan pada bisnis biasa. Pelayanan dalam dunia kenotariatan harus tetap mengikuti rambu-rambu dalam UUJN dan Kode Etik Jabatan Notaris, sebab notaris berada dalam ranah pelayanan professional yang menunjang tinggi etika professional. Sikap pelayanan yang salah bagi seorang notaris karena mengorbankan martabat dan keluruhan notaris dengan tidak mengindahkan kode etik. Motivasinya pun tidak murni untuk melayani masyarakat semata, melainkan kuat dengan unsur promosi diri sendiri. Padahal kode etik adalah koridor penyelamat profesi jabatan notaris yang luhur dan bermartabat. ${ }^{13}$

Penulis berpendapat bahwa diperlukan adanya kategori batasan yang jelas terkait publikasi dan promosi jabatan notaris. Urgensi terhadap kategori batasan tersebut adalah agar mendapat kepastian hukum mengenai apa yang boleh dan tidak boleh dilakukan oleh notaris dalam kegiatan kesehariannya. Kategori batasan yang dimaksud merupakan ada atau tidaknya unsur kesengajaan dalam memuat keterangan jabatan notarisnya dan/ atau mencantumkan alamat kantor maupun nomor telepon kantor yang bersifat informatif secara tersirat mau pun tidak tersirat mengandung unsur ajakan, adanya kegiatan publikasi yang bersifat persuasif untuk melakukan kerja sama dan/atau menggunakan jasa notaris tersebut, serta memuat kalimat-kalimat yang dapat memicu masyarakat dan menggiring

12 Agus Santoso. 2014. Hukum, Modal, dan Keadilan, Jakarta: Kencana, Prenada Media Group, hlm. 118.

13 Pengurus Pusat Ikatan Notaris. 2008. Jati Diri Notaris di Indonesia: Dulu, Sekarang dan Di Masa Datang, Jakarta: PT. Gramedia Pustaka, hlm. 215. pembacanya bahwa notaris tersebut merupakan notaris terkenal/handal/kompeten, padahal semua notaris diwajibkan untuk memiliki sifat amanah (dapat dipercaya), tidak menyalahgunakan jabatannya, melayani klien dengan sepenuh hati dan jujur dalam melaksakan tugas dan wewenangnya, sehingga tidak ada notaris yang istimewa karena adanya publikasi dan promosi diri tersebut.

Meskipun begitu, masih ditemukan beberapa pihak yang melakukan publikasi dan/ atau promosi jabatan sebagai notaris dalam berbagai macam media, baik itu media tulis maupun media elektronik, dalam pembahasan ini khususnya pada aplikasi android yang sengaja dibuat untuk memuat alamat kantor serta nomor telepon kantor notaris dianggap merupakan bentuk publikasi jabatan notaris. Sehingga dibutuhkan pengawasan oleh Dewan Kehormatan Notaris mau pun Majelis Pengawas Notaris terhadap pihak yang melakukan pelanggaran terhadap Kode Etik Jabatan Notaris tersebut untuk mencegah timbulnya pelanggaran seperti itu dikemudian hari. Ikatan Notaris Indonesia (INI) sebagai wadah yang menaungi para notaris Indonesia dapat memberikan suatu keputusan maupun surat edaran mengenai eksistensi aplikasi android yang digunakan oleh notaris tanpa maksud dan tujuan yang jelas dan menyiratkan ajakan, promosi, kata-kata persuasif sejenisnya agar notaris yang sudah terlanjur menggunakan aplikasi android yang memiliki unsur promosi jabatan dapat menarik kembali aplikasinya dari toko aplikasi android. disamping itu, upaya lainnya adalah dengan melakukan revisi pada peraturan pedoman jabatan notaris, yaitu Undang-undang Jabatan Notaris dan Kode Etik Jabatan Notaris yang merupakan seperangkat aturan yang berperan untuk menentukan tingkat kualitas notaris Indonesia 
agar dapat disesuaikan dengan kondisi kemajuan teknologi masa kini.

Suatu bentuk upaya yang dapat dilakukan untuk menegakan Kode Etik Jabatan Notaris terhadap adanya pelanggaran kode etik, yang merupakan particular rules atau specific rules, yaitu ketentuan yang hanya berlaku secara khusus bagi setiap orang yang memangku jabatan notaris adalah dengan menerapkan sanksi yang termaktub pada Kode Etik yang terkait, dalam hal ini merupakan Pasal 6 Kode Etik Jabatan Notaris mengatur mengenai sanksi yang dapat dikenalan kepada anggota perkumpulan yang melakukan pelanggaran rambu-rambu kode etik. Sanksi tersebut dapat berupa teguran, peringatan, skorsing (pemecatan sementara) dari keanggotaan perkumpulan, onzetting (pemecatan) dari perkumpulan, dan pemberhentian tidak hormat dari keanggotaan perkumpulan. ${ }^{14}$

Hakekatnya seluruh pasal dalam UUJN mengandung ancaman hukuman, apabila Notaris mengabaikan keluhuran martabat atau jabatannya, melakukan kesalahan-kesalahan lain, baik di dalam maupun di luar menjalankan jabatannya sebagai Notaris. Pasal 16 huruf a UUJN, Notaris diwajibkan bertindak jujur, seksama, mandiri, tidak berpihak dan menjaga kepentingan para pihak yang terkait dalam perbuatan hukum. ${ }^{15}$ Dewan Kehormatan Notaris mau pun Majelis Pengawas Notaris dapat menjatuhkan hukuman kepada notaris yang melanggar Kode Etik terkait publikasi dan promosi diri sesuai dengan ketentuan UUJN dan Kode Etik Jabatan Notaris.

14 Ismantoro Dwi Yuwono. 2013. Memahami Berbagai Etika Profesi dan Pekerjaan, Yogyakarta: Medpress Digital, Hlm. 197.

15 Herlin Budiono. 2007. Kumpulan Tulisan Hukum Perdata di Bidang Kenotariatan, Bandung: Citra Aditya Bakti, hlm.22.
Analisis Timbulnya Persaingan Tidak Sehat Antar Sesama Rekan Notaris Disebabkan oleh Pelanggaran Kode Etik Jabatan Notaris

Kaidah yang tercermin dari Kode Etik Jabatan Notaris sebagai sebuah profesi jabatan antara lain, pelayanan, nilai-nilai luhur, orientasi pada masyarakat dan persaingan yang sehat.

Kegiatan promosi dan publikasi jabatan notaris dapat menjadi salah satu alasan timbulnya persaingan usaha tidak sehat antar sesama rekan notaris. Hal ini berkesesuaian dengan Ketentuan Kode Etik Jabatan Notaris Pasal 4 angka 9 yang mengatur larangan notaris melakukan usaha-usaha, baik langsung maupun tidak langsung yang menjurus ke arah timbulnya persaingan yang tidak sehat sesama rekan notaris.

Meskipun notaris itu merupakan pejabat umum karena melaksanakan tugas dan kewajiban pemerintah, namun notaris bukanlah pegawai negeri. Notaris diangkat oleh pemerintah, namun notaris tidak menerima gaji dan dana pensiun dari pemerintah. Penghasilan notaris diperoleh dari honorarium kliennya. ${ }^{16}$ Oleh sebab itulah, notaris dalam menjalankan jabatannya adalah bentuk usaha untuk mendapatkan kepercayaan dari masyarakat sebagai klien notaris (trusted service).

Pada dasarnya persaingan usaha itu mutlak terjadi (conditio sine qua non). Namun ada kalanya persaingan usaha itu berada dalam parameter sehat dan dapat juga tidak sehat. ${ }^{17}$

Persaingan usaha tidak sehat adalah per-

16 Ghansam Anand, op.cit., hlm. 35.

17 Susanti Adi Nugroho. 2014. Hukum Persaingan Usaha di Indonesia, dalam Teori dan Praktik Serta Penerapan Hukumnya. Jakarta: Kencana Prenadaedia Group, hlm. 3. 
saingan usaha antar pelaku bisnis dan usaha dalam menjalankan kegiatan produksi dan atau pemasaran barang dan atau jasa, yang dilakukan dengan cara tidak jujur atau melawan hukum atau menghambat persaingan usaha. ${ }^{18}$

Maka, ketentuan larangan melakukan usaha-usaha yang menjurus ke arah timbulnya persaingan usaha tidak sehat antar sesama rekan notaris sangat berkaitan dengan eksistensi aplikasi notaris yang bertujuan untuk publikasi dan promosi jabatan notaris. Hal tersebut jelas bertentangan dengan ketentuan pada Kode Etik Jabatan Notaris, karena Notaris dilarang melakukan upaya-upaya yang tujuan mendapatkan klien sebanyak-banyaknya dengan tidak mengindahkan ketentuan pada Undang-undang maupun Kode Etik Jabatan Notaris.

Akan tetapi dalam praktiknya tidak semua notaris melakukan hal tersebut, namun hanya sebagian notaris. Oleh karena hal tersebut hanya dilakukan oleh sebagian Notaris maka terdapat notaris-notaris lainnya yang tidak turut melakukan hal demikian, sehingga menimbulkan kesenjangan antar rekan notaris itu sendiri, dan hal tersebut akan menimbulkan persaingan yang tidak sehat, karena sebagian notaris tersebut memilih cara-cara yang tidak dibenarkan, sedangkan lainnya tetap berpegang teguh pada Undang-Undang dan Kode Etik. ${ }^{19}$ Pelayanan yang paling tepat untuk notaris adalah pelayanan yang berpaku

18 M. Udin Silalahi. 2007. Perusahaan Saling Mematikan \& Bersekongkol: Bagaimana Cara Memenangkan?, Jakarta: PT Elex Media Komputindo, hlm. 4.

19 Felly Faradina. 2011. Persaingan Tidak Sehat Antar Rekan Notaris Sebagai Dampak dari Penetapan Tarif Jasa Notaris Dibawah Standar Ditinjau dari Undang-Undang Nomor 20 Tahun 2004 tentang Jabatan Notaris dan Kode Etik, Tesis, Universitas Indonesia, hlm. 4. pada Kode Etik Jabatan Notaris yang telah disahkan dan disepakati. ${ }^{20}$

Suatu pelanggaran terhadap Kode Etik Jabatan Notaris yang bertujuan untuk mendapatkan klien sebanyak-banyaknya akan menimbulkan permasalahan antar sesama rekan notaris, terciptanya kesenjangan dan ketidakharmonisan hubungan teman seprofesi yang dimana seharusnya notaris sebagai jabatan yang bermartabat tinggi tidak diperkenankan melakukan publikasi maupun promosi terhadap jabatan yang diembannya sebab hal itu dapat menurunkan integritas notaris dan mengurangi sifat kemandirian serta ketidakberpihakan yang dimiliki oleh notaris. Namun, hal tersebut tentu saja memiliki kategori batasan, misalnya notaris yang melakukan publikasi berkaitan dengan kegiatan sehari-hari dalam menjalankan jabatan Notarisnya maupun yang berbagi pengetahuan dalam bentuk tulisan ilmiah dan penelitian. Publikasi dalam bentuk artikel ilmiah yang bertujuan untuk menyumbangkan pemikiran dan memperluas wawasan masyarakat dinilai tidak melanggar kategori batasan selama tidak terdapat aspek penyebarluasan informasi yang dapat menggiring masyarakat untuk menggunakan jasa notaris yang bersangkutan.

Kehormatan dan keluruhan profesi jabatan notaris harus tetap terjaga agar masyarakat tidak meremehkan dan mengabaikan jabatan notaris, sehingga dirasa penting peran dan fungi Dewan Kehormatan untuk ditingkatkan. Citra dan wibawanya sebagai institusi harus tinggi dan mendapat pengakuan semua pihak sehingga Dewan Kehormatan bisa menjadi acuan bagi para pihak yang ingin mencari kebenaran dan mendapat solusi yang adil dan jujur. Dengan demikian, para pihak yang merasa dirugikan oleh notaris di-

20 Pengurus Pusat Ikatan Notaris, op.cit. 
harapkan akan melaporkan kasusnya terlebih dahulu kepada Dewan Kehormatan sebelum ke Majelis Pengawas. Dewan Kehormatan dirasa lebih tepat karena bisa menuntaskan kasus tanpa meluaskan cakupan masalah. ${ }^{21}$

\section{PENUTUP}

\section{Kesimpulan}

1. Penggunaan aplikasi android oleh Notaris dapat menjadi suatu kemajuan di bidang kenotariatan apabila dimanfaatkan dengan sebaik-baiknya untuk meningkatkan kualitas pelayanan dan integrase jabatan notaris di masyarakat. Dalam proses mewujudkan sebuah inovasi tersebut haruslah tidak melanggar pilar-pilar hukum yang bertujuan melindungi jabatan notaris dari berbagai risiko yang dapat ditimbulkan dari pratik profesi jabatan notaris.

2. Pasal 4 angka 3 Kode Etik Jabatan Notaris mengatur larangan untuk mempublikasi dan promosi jabatan notaris termasuk melalui media elektronik, maka dengan memasukan kalimat ajakan/persuasif dan sejenisnya pada aplikasi android yang dibuat oleh notaris termasuk dalam suatu upaya untuk publikasi dan promosi jabatan notaris.

3. Larangan untuk publikasi dan promosi jabatan notaris berkaitan dengan potensi timbulnya persaingan tidak sehat antar sesama rekan notaris dikarenakan sebagian notaris melakukan upaya yang dilarang oleh UUJN dan Kode Etik Jabatan Notaris sedangkan sebagian notaris tidak. Persaingan tidak sehat akan menciptakan kesenjangan dan ketidakharmonisan antar sesama rekan notaris.

\footnotetext{
21 Pengurus Pusat Ikatan Notaris, op.cit., hlm 202.
}

\section{Saran}

Agar terciptanya sinergi dan keharmonisan antar sesama rekan notaris dapat melaksanakan ketentuan UUJN dan Kode Etik Jabatan Notaris sebagai pilar pendukung yang melindungi profesi jabatan notaris. Alangkah baik jika penggunaan aplikasi android dikaji lebih dalam oleh Ikatan Notaris Indonesia sebagai potensi inovasi untuk meningkatkan kualitas pelayanan terhadap masyarakat yang kemudian dapat disusul dengan penyesuaian terhadap peraturan keanggotaan agar dapat mengikuti kemajuan teknologi dalam dunia kenotariatan.

\section{BIBLIOGRAFI}

Anand, Ghansam. 2018. Karakteristik Jabatan Notaris di Indonesia, Jakarta: Prenamedia Group.

Budiono, Herlin. 2007. Kumpulan Tulisan Hukum Perdata di Bidang Kenotariatan, Bandung: Citra Aditya Bakti.

Faradina, Felly. 2011. Persaingan Tidak Sehat Antar Rekan Notaris Sebagai Dampak dari Penetapan Tarif Jasa Notaris Dibawah Standar Ditinjau dari Undang-Undang Nomor 20 Tahun 2004 tentang Jabatan Notaris dan Kode Etik, Tesis, Jakarta: Universitas Indonesia.

Harsono, Irvano Gibriansyah. 2019. Larangan Etika Terkait Publikasi dan Promosi Jabatan Bagi Notaris Melalui Media Elektronik, Tesis, Surabaya: Universitas Airlangga.

Ismayani, Ani. 2018. Cara Mudah Membuat Aplikasi Pembelajaran Berbasis Android dengan Thunkable. Jakarta: Elex Media Komputindo

Kie, Tan Thong. 2007. Studi Notariat dan Serba-Serbi Praktek Notaris, cet. 1, Jakarta: PT. Ichtiar Baru van Hoeve. 
Marzuki, Peter Mahmud. 2010. Penelitian Hukum, Kencana Jakarta: Prenada Media Group.

Nugroho, Susanti Adi. 2014. Hukum Persaingan Usaha di Indonesia, dalam Teori dan Praktik Serta Penerapan Hukumnya. Jakarta: Kencana Prenadaedia Group.

Rahman, Aulia. 2019. Cara Membuat Aplikasi Android: Hanya 5 menit, Luminos Publish.

Santoso, Agus. 2014. Hukum, Modal, dan Keadilan, Jakarta: Kencana, Prenada Media Group.
Silalahi, M. Udin. 2007. Perusahaan Saling Mematikan \& Bersekongkol: Bagaimana Cara Memenangkan?, Jakarta: PT Elex Media Komputindo.

Pengurus Pusat Ikatan Notaris. 2008. Jati Diri Notaris di Indonesia: Dulu, Sekarang dan Di Masa Datang, Jakarta: PT. Gramedia Pustaka

Yuwono, Ismantoro Dwi. 2013. Memahami Berbagai Etika Profesi dan Pekerjaan, Yogyakarta: Medpress Digital 